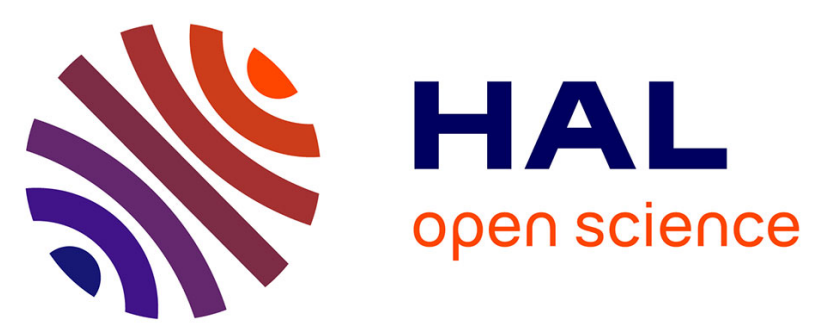

\title{
Sensitivity studies on the photolysis rates calculation in Amazonian atmospheric chemistry? Part I: The impact of the direct radiative effect of biomass burning aerosol particles
}

\author{
L. M. M. Albuquerque, K. M. Longo, S. R. Freitas, T. Tarasova, Artemio \\ Plana-Fattori, C. Nobre, L. V. Gatti
}

\section{To cite this version:}

L. M. M. Albuquerque, K. M. Longo, S. R. Freitas, T. Tarasova, Artemio Plana-Fattori, et al.. Sensitivity studies on the photolysis rates calculation in Amazonian atmospheric chemistry? Part I: The impact of the direct radiative effect of biomass burning aerosol particles. Atmospheric Chemistry and Physics Discussions, 2005, 5 (5), pp.9325-9353. hal-00303942

\section{HAL Id: hal-00303942 \\ https://hal.science/hal-00303942}

Submitted on 28 Sep 2005

HAL is a multi-disciplinary open access archive for the deposit and dissemination of scientific research documents, whether they are published or not. The documents may come from teaching and research institutions in France or abroad, or from public or private research centers.
L'archive ouverte pluridisciplinaire HAL, est destinée au dépôt et à la diffusion de documents scientifiques de niveau recherche, publiés ou non, émanant des établissements d'enseignement et de recherche français ou étrangers, des laboratoires publics ou privés. 


\section{Sensitivity studies on the photolysis rates calculation in Amazonian atmospheric chemistry - Part l: The impact of the direct radiative effect of biomass burning aerosol particles}

L. M. M. Albuquerque ${ }^{1,2}$, K. M. Longo ${ }^{1}$, S. R. Freitas ${ }^{1}$, T. Tarasova ${ }^{1}$, A. Plana Fattori ${ }^{3}$, C. Nobre ${ }^{1}$, and L. V. Gatti ${ }^{4}$

${ }^{1}$ Centro de Previsão de Tempo e Estudos Climáticos (CPTEC-INPE), Brazil

${ }^{2}$ Current affiliation: Universidade Federal de Mato Grosso do Sul, UFMS, DHT, Brazil

${ }^{3}$ On leave from: Departamento de Ciências Atmosféricas, Universidade de São Paulo, Brazil

${ }^{4}$ Instituto de Pesquisas Energeticas e Nucleares (IPEN /USP), Brazil

Received: 6 July 2005 - Accepted: 29 July 2005 - Published: 28 September 2005

Correspondence to: L. M. M. Albuquerque (leilamma@cptec.inpe.br)

(C) 2005 Author(s). This work is licensed under a Creative Commons License.

ACPD

$5,9325-9353,2005$

Impact of smoke aerosol on the photolysis rates

L. M. M. Albuquerque et al.

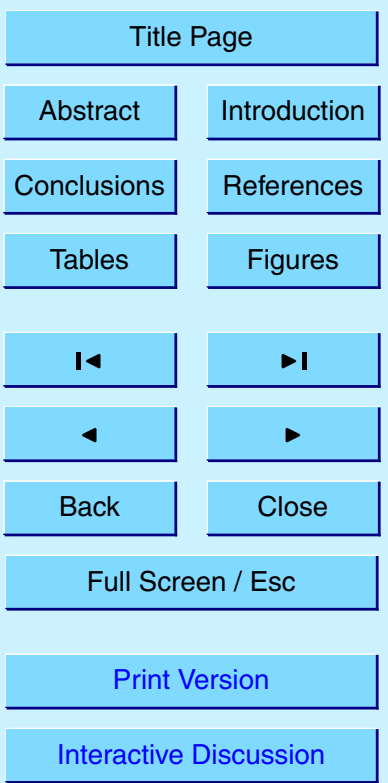




\section{Abstract}

The impact of the direct radiative effect of the aerosol particles on the calculation of the photolysis rates and consequently on the atmospheric chemistry in regional smoke clouds due to biomass burning over the Amazon basin is addressed in this work. It explores a case study for 19 September 2002 at LBA-RACCI-SMOCC (The Large-Scale Biosphere-Atmosphere experiment in Amazonia - Radiation, Cloud, and Climate Interactions - Smoke, Aerosols, Clouds, Rainfall and Climate) pasture site in SW Amazonia. The Tropospheric Ultraviolet Visible radiation model (TUV) version 4.2, (Madronich et al., 1987) is used for the photolysis rates calculation considering the layer aerosol optical depth from the Coupled Aerosol Tracer Transport model to the Brazilian Regional Atmospheric Modeling System (CATT-BRAMS) (Freitas et al., 2005). A dynamical aerosol model (Procópio et al., 2003) is included in the radiative transfer model to take into account the high temporal variability of the aerosol optical thickness. This methodology is tested by comparing modeled and measured clear sky solar irradi15 ances. The results show a good agreement with measured PAR radiation values. The actinic flux attenuation, for AOT $(500 \mathrm{~nm})$ values around 1.94, decreases the photolysis rates by about $70 \%$ in the presence of near-ground smoke aerosol and above the smoke layer the photolysis process tends to increase by about $40 \%$. A simulation of the ozone production is carried out using a one-dimensional photochemical box model and comparisons with observation are shown.

\section{Introduction}

As part of The Large-Scale Biosphere - Atmosphere Experiment in Amazonia's RACCI (Radiation, Cloud, and Climate Interactions) - SMOCC (Smoke, Aerosols, Clouds, Rainfall and Climate) campaign (LBA-RACCI-SMOCC-2002) measurements of concentrations and fluxes of aerosol particles, $\mathrm{O}_{3}, \mathrm{NO}_{x}$ and VOCs were carried out at forest and pasture sites in Rondônia, in the southwest part of the Amazon Basin. This
ACPD

$5,9325-9353,2005$

Impact of smoke aerosol on the photolysis rates

L. M. M. Albuquerque et al.

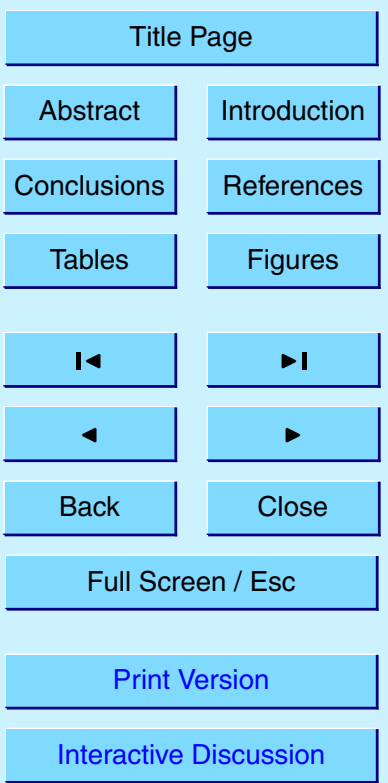

EGU 
campaign was conducted during the dry-to-wet season transition period (SeptemberOctober) (Andreae et al., 2004). The available data has been used to study the oxidative capacity, the particle production and the carbon cycle in the Amazon atmosphere, Claeys et al. (2004).

5 Scientific interest in the impact of biomass burning on atmospheric chemistry grew when it became evident that it is an important source of atmospheric pollution and its products could affect large areas of the world as a consequence of long-range transport. The majority of biomass burning is carried out in tropical regions like the Amazon Basin, where slash-and- burn techniques are widely utilized for both primary 10 deforestation and seasonal burning of secondary forests and pastures, Fearnside et al. (2005). Vegetation is the major fuel consumed in biomass burning in this region and the smoke produced is composed predominantly of organic matter, Graham et al. (2003). The smoke aerosols emitted either by natural or anthropogenic biomass burning fires represent a significant local alteration of the Amazonian atmospheric environment. Their effects depend on the optical properties of the smoke aerosols and surface characteristics and it can warm the atmosphere while cooling the surface, affecting the surface fluxes of sensible and latent heat. On the other hand, on a regional and global scale, the biomass burning emissions to the atmosphere may change the atmospheric radiative balance and hydrological cycle through aerosol particles direct effects, absorbing, reflecting and scattering the solar radiation, and indirectly by altering the microphysics and the dynamics of cloud formation. Biomass burning is also a substantial source of oxygenated compounds for the Amazonian atmosphere during the dry season. These compounds are very important because they are transformed photochemically into radicals in the atmosphere. The emissions from vegetation fires

are particularly important because they contribute to enlarging the volatile organic compound (VOCs) sources, contributing significantly to the production of $\mathrm{OH}$ radicals and the aerosol budget (Weavers et al., 1998). Within the Amazon region, isoprene is the most prominent compound, while formaldehyde is the most predominant OVOC species (Kesselmeier et al., 2002).
ACPD

5, 9325-9353, 2005

Impact of smoke aerosol on the photolysis rates

L. M. M. Albuquerque et al.

Title Page

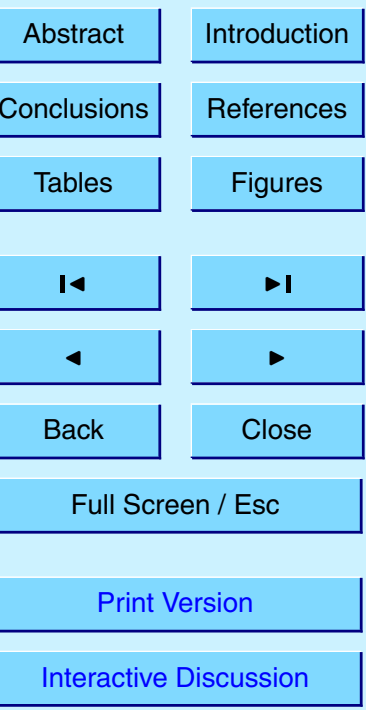

EGU 
The low troposphere atmospheric chemistry itself is driven by solar radiation directly, through photolysis, and indirectly, through the determination of the boundary layer diurnal cycle. The presence of aerosol particles affects directly the photochemistry by modifying the actinic flux scattering and absorbing solar radiation. Yamasoe et al. (2005)

5 reported significant reductions of up to $50 \%$ of the downward PAR irradiance at the top of canopy under smoky conditions at the top of the canopy in an Amazonia forest. Therefore, to estimate the biomass burning effects on the Amazonian atmospheric chemistry, it is important to use accurate calculations of the photolysis rates, as well as to take into account the high temporal variability in smoke aerosol optical proper10 ties. Usually atmospheric chemistry models adopt an average diurnal chemical cycle with mean photolysis rate values. Several methods suitable for these calculations are discussed at Filyushkin et al. (1994). These methods give accurate results and can be applied for any averaged time period of an arbitrary duration, but they are not valid in the case of significant diurnal variations of optical parameters of the atmosphere and underlying surface.

The objective of this study is to describe the impact of the direct radiative effect of the aerosol particles on the calculation of the photolysis rates and consequently on the atmospheric chemistry in the regional smoke cloud due to biomass burning over the Amazon Basin.

\section{The case study}

With the aim of obtaining detailed information on the photolysis rate coefficient, which are expected to be strongly influenced by smoke aerosols, a case study was chosen during a day of intense biomass burning occurrence around the Fazenda Nossa Senhora $\left(10^{\circ} 45^{\prime} 44^{\prime \prime} \mathrm{S}, 62^{\circ} 21^{\prime} 27^{\prime \prime} \mathrm{W}\right)$, the LBA-RACCI-SMOCC pasture experimental site in the State of Rôndonia (NW Amazonia). Clearing of rain forest by fire in Rondônia has taken place since 1968, creating a typical fishbone-like pattern of plantations, pastures, degraded land and forest patches, Andreae et al. (2002). The pasture is a rural

ACPD

$5,9325-9353,2005$

Impact of smoke aerosol on the photolysis rates

L. M. M. Albuquerque et al.

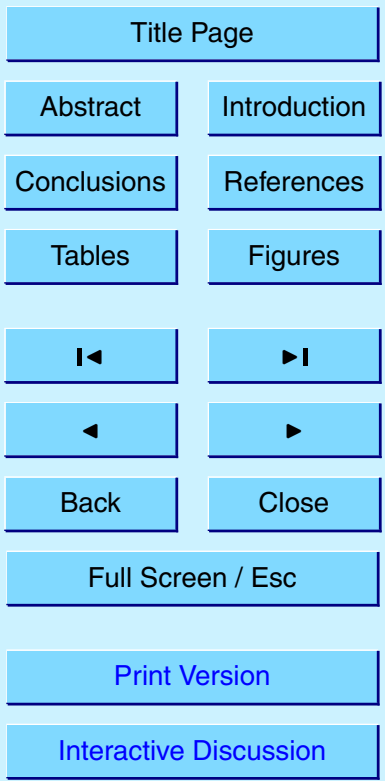

EGU 
site and is characterized by small seasonal mean air temperature variations, ranging from $25-26^{\circ} \mathrm{C}$ during the dry season (September/October). Mean annual relative humidity values are high, with averages of about $70 \%$ in the dry season. Prevailing wind speeds are relatively low $\left(\sim 1.5 \mathrm{~ms}^{-1}\right)$ with a minimum during night time. Precipitation

5 in this region shows a seasonal cycle with lowest values in July and is highest from November to April (Andreae et al., 2002).

The chosen study day, 19 September 2002, was a day with nearly cloudless skies in the morning and scattered small cumulus clouds during the rest of the day over Rôndonia. Northern winds, bringing clean air masses from pristine areas, were re10 sponsible for a relatively clean atmosphere in Rôndonia during the first morning hours, despite of the intense biomass burning activity on the previous days and the dense regional smoke layer covering a large area of South America. Figure 1 shows a map with aerosol optical thickness $(550 \mathrm{~nm})$ from MODIS-TERRA over South America and a zoom over the Rôndonia State around 14:00 UTC on 19 September 2002. Along the 15 dat day, burning activities have grown in intensity, with several vegetation fires detected in the region and the aerosol optical thickness $(500 \mathrm{~nm})$ sharply increased from values below 1.0 to $2.3( \pm 1.1)$ (see the detail in the Fig. 6). Smoke plumes from isolated fires could be seen even on visible channel GOES-8 imagery (Fig. 2). Figure 3 shows the temperature vertical profile from radiosounding data of the LBA-RACCI-SMOCC field experiment for this case study. The main feature of the temperature profile is the strong temperature inversion between $300 \mathrm{~m}$ and $650 \mathrm{~m}$.

\section{Methodology}

In this study the photolysis rates are obtained using a radiative transfer model along with a dynamical aerosol model considering complex atmospheric optical situations. To
ACPD

$5,9325-9353,2005$

Impact of smoke aerosol on the photolysis rates

L. M. M. Albuquerque et al.

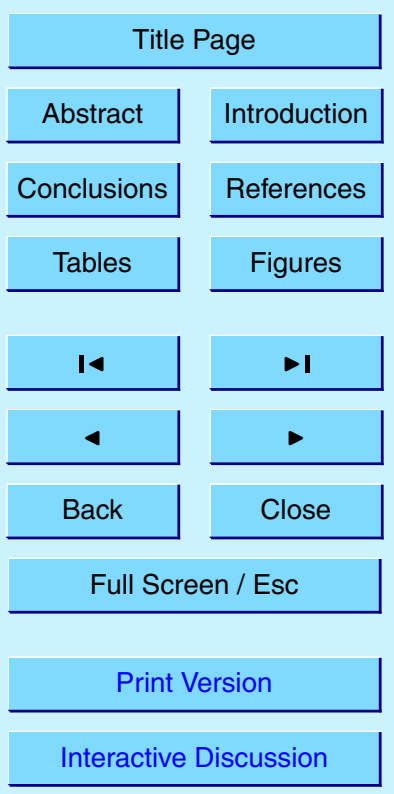

EGU 
tical profiles are build as a combination of model results and AERONET data (Holben et al.,1998).

The photolysis rates ( $j$ - values) describe quantitatively the frequency of the atmospheric photolysis reactions. The actinic radiation $F(\lambda)$ and photolysis rates are 5 obtained by the expression:

$j_{x}=\int \sigma_{x}(\lambda) \cdot \phi_{x}(\lambda) \cdot F(\lambda) \cdot d \lambda$,

where $\sigma_{x}(\lambda)$ is the absorption cross section of the chemical species $x, \phi_{x}(\lambda)$ is the quantum yield of the reaction. This expression can be used to calculate photolysis rates under real or simulated atmospheric conditions with the actinic flux radiation measured or modeled. Measurements of the actinic radiation are rare and often radiative transfer models are used to quantify the radiation flux though the atmosphere.

The Tropospheric Ultraviolet-Visible, TUV model version 4.2, is used to calculate spectral actinic flux and photolysis rates for each molecule of interest, taking the interaction between aerosol particles and radiation into account (Madronich, 1987). This 15 model considers the solar spectral irradiance incident at the top of the Earth's atmosphere and calculates the propagation of this radiation as it passes through the atmosphere (van Hoosier et al., 1998; Neckel and Labs, 1984). A four-stream discrete ordinate scheme radiation solver is employed and the calculation is repeated for each wavelength between $150 \mathrm{~nm}$ and $420 \mathrm{~nm}$, with a spectral resolution of $1 \mathrm{~nm}$, and between $420 \mathrm{~nm}$ and $700 \mathrm{~nm}$ with a spectral resolution of $10 \mathrm{~nm}$. To account for the vertical variations of atmospheric constituents, the model is implemented to subdivide the atmospheric levels into 115 vertical layers of irregular vertical thickness $(\sim 20 \mathrm{~m})$ from 0 to $5 \mathrm{~km}$ and 94 vertical layers of $1 \mathrm{~km}$ vertical thickness from 5 to $100 \mathrm{~km}$. Following that, the spectral actinic flux associated with the direct solar beam and the downwelling and upwelling diffuse radiation fields are calculated for each altitude and each wavelength. The radiation field is modified by Rayleigh and Mie scattering and absorption due to several gases and particles, as well as Lambertian reflection at the surface. Gaseous absorbers include $\mathrm{O}_{2}$ and $\mathrm{O}_{3}$, as well as $\mathrm{SO}_{2}$ and $\mathrm{NO}_{2}$ when these

\section{Impact of smoke aerosol on the photolysis rates}

L. M. M. Albuquerque et al.

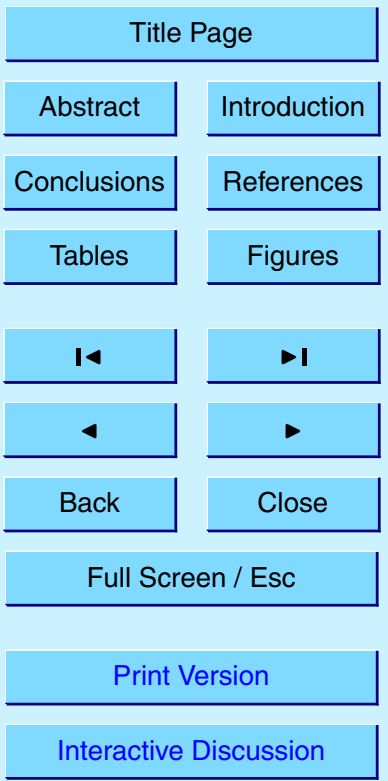

EGU 
are present in representative concentrations. Aerosols can absorb or scatter radiation, depending on their size distribution and chemical composition.

In order to account for aerosol particles in the actinic flux and photolysis rates calculations, aerosol particles loading must be added in the TUV one-dimensional col5 umn. Four different types of aerosol particles are considered in this study: smoke, continental, stratospheric and upper atmospheric. For the smoke aerosol, climatological properties derived from a three years of optical properties retrieval obtained for an Amazonian observational site of the AERONET sun photometer network are used (Procópio et al., 2003). Basically, the smoke aerosol optical depth is measured by a 10 sun photometer and the single scattering albedo, $\omega_{0}$, and asymmetry parameter, $g$, of the phase function are computed with a dynamical aerosol model, as functions of the aerosol optical depth. The other aerosol models are from WMO (1986). The smoke and continental aerosol models are added into the tropospheric layers $0-5 \mathrm{~km}$ and 5$12 \mathrm{~km}$, while the stratospheric and upper atmospheric aerosol model are incorporated 15 into the $12-30 \mathrm{~km}$ and $30-100 \mathrm{~km}$ layers. The optical properties for smoke aerosols are accessed by the TUV model using precalculated and tabulated optical parameter tables and these values are interpolated in the TUV spectral range $(150-700 \mathrm{~nm})$. Figures 4 and 5, respectively, show spectral smoke and continental aerosol optical parameters as functions of aerosol optical thickness at $500 \mathrm{~nm}$. The main feature in the Figure 4 is the single scattering albedo maximum between $300 \mathrm{~nm}$ and $440 \mathrm{~nm}$ ranges and the variability of this parameter with optical depth values. This aspect is relevant because it represents a range of the spectrum where important photolysis process take place, such as $\mathrm{NO}_{2}+\mathrm{hu} \rightarrow \mathrm{O}\left({ }^{3} \mathrm{P}\right)+\mathrm{NO}$, which is dominant source of the tropospheric ozone following $\left.\mathrm{O}^{3} \mathrm{P}\right)+\mathrm{O}_{2}+\mathrm{M} \rightarrow \mathrm{O}_{3}+M$.

25 A normalized vertical distribution of the aerosol extinction coefficient in the boundary layer of the atmosphere is calculated by the transport model CATT-BRAMS in order to have a description of the evolution of the boundary layer diurnal cycle (Fig. 6). These profiles are combined with an average aerosol optical thickness from several AERONET sites in Rôndonia (SW Amazon) shown in the detail of the Fig. 6. For the

Impact of smoke aerosol on the photolysis rates

L. M. M. Albuquerque et al.

Title Page

Abstract Introduction

Conclusions

References

Tables

Figures

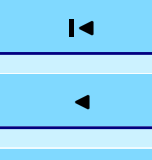

$\rightarrow$

Back

Close

Full Screen / Esc

Print Version

Interactive Discussion 
uppermost layers, the aerosol extinction coefficients at $550 \mathrm{~nm}$ are constant following WMO (1986) and are shown in Table 1.

A review of the spectral surface albedo over different types of land surfaces available in the literature are shown in Fig. 7. Although the savannas (cerrado) and forest values 5 measured in the Amazon Basin by Tsay et al. (1998) would be more representative of the region they are nonexistent for the photochemistry spectral range of interest, around $200-480 \mathrm{~nm}$. Tests to evaluate the sensitivity of the actinic flux calculation with the surface albedo were performed and the results showed low dependence in this spectral region. As example, the difference in the actinic flux is less than $1 \%$ when assuming the surface albedo for grass (Fig. 7) or zero.

Other inputs to the TUV model are atmospheric profiles from radiosondes and a composed $\mathrm{O}_{3}$ profiles with averaged aircraft measurements for the lower troposphere and climatological profiles for the upper levels. The total $\mathrm{O}_{3}$ column was around $305 \mathrm{DU}$, which very well compared with the SHADOZ data for the sites of Natal and Paramaribo (Thompson et al., 2003). Additional model assumptions include cloudless skies.

Atmospheric chemical transformations are modeled using the OZIPR model version 2.0 (Tonnesen, 2000). OZIPR is a research-oriented version of EPA's OZIPP (Ozone Isopleth Plotting Package) computer modeling program. The OZIPR model is a onedimensional box model with a time-varying box height (i.e. the height of the mixing layer). The model inputs include initial concentrations and hourly emission rates for the relevant chemical species and meteorological parameters, such as, temperature, humidity, mixing heights, and atmospheric pressure. To allow flexibility, the chemical species and reactions are not fixed in the program code, but can be provided as inputs to the model and for this study the chemical mechanism chosen was the same in MOZART-2 (Horowitz et al., 2003). This mechanism, which includes 168 gas phase reactions, 33 photochemical reactions and the isoprene scheme by Orlando and Tyndall (2002), emphasizes the processes of tropospheric ozone and its precursors' production.

In the OZIPR model, a well mixed box is moved at the average wind speed along
ACPD

5, 9325-9353, 2005

Impact of smoke aerosol on the photolysis rates

L. M. M. Albuquerque et al.

Title Page

Abstract Introduction

Conclusions

References

Tables Figures
14

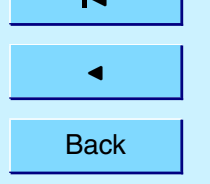

Close
Full Screen / Esc

Print Version

Interactive Discussion 
a trajectory through the study area. As the boxes moves, its height increases due to the mixing height rise from the sun's heating. This rise results in a decrease in the concentrations of the primary species in the box. In addition, aged materials that were in the air above are mixed down into the box when the mixed layer height increases.

5 At the same time, fresh emissions are added through the bottom of the box increasing the concentrations in the box for some species. In this case study the mixed height is assumed to be 110 meters at 12:00 UTC (8:00, local time) with $1754 \mathrm{~m}$ at 21:00 UTC (17:00, local time) (Fish et al., personal communication). The hourly emissions data for $\mathrm{NO}_{\mathrm{x}}, \mathrm{CO}, \mathrm{C}_{2} \mathrm{H}_{6}, \mathrm{C}_{3} \mathrm{H}_{8}, \mathrm{C}_{2} \mathrm{H}_{4}, \mathrm{C}_{3} \mathrm{H}_{6}, \mathrm{C}_{4} \mathrm{H}_{10}, \mathrm{CH}_{3} \mathrm{COCH}_{3}$, ISOP, $\mathrm{C}_{10} \mathrm{H}_{16}, \mathrm{CH}_{2} \mathrm{O}$, $10 \mathrm{CH}_{3} \mathrm{OH}, \mathrm{CH}_{4}, \mathrm{~N}_{2} \mathrm{O}$ and $\mathrm{H}_{2}$ are obtained by multiplying the total amount of biomass burned within a grid cell during $24 \mathrm{~h}$ by the respective specie emission factor. The total amount of biomass burned was determined through Freitas et al. (2005) technique and the emission factors for pyrogenic species were obtained from Andreae and Merlet (2001). In the OZIPR model the photolysis processes are represented as a function of

15 the sun's zenith angle and thus is highly dependent on the time of day and the season. In this study a complex lookup table was build to represent the photolysis processes a function of the sun's zenith angle and total column aerosol optical thickness using TUV capabilities.

\section{Results}

20 The radiation model results show a significant attenuation in the actinic flux due the presence of the aerosol particles (Fig. 8). In the spectral range between $320 \mathrm{~nm}$ and $540 \mathrm{~nm}$, at 12:00 UTC (zenith angle equal to 61.03) and with an AOT (500 nm) of 0.84, the reduction reaches $40 \%$. At 16:00 UTC (zenith angle equal to 12.13) and AOT $(500 \mathrm{~nm})$ of 0.85 , the reduction is below $45 \%$ at wavelength range of $290-340 \mathrm{~nm}$. For the highest value of AOT $(500 \mathrm{~nm})$ for this day (equal 1.94 at 20:00 UTC), the attenuation reaches $70 \%$. Figure 9 compares observed and modeled values of the Photosynthetically Active Radiation (PAR), which results from the integration of the global (direct

ACPD

5, 9325-9353, 2005

Impact of smoke aerosol on the photolysis rates

L. M. M. Albuquerque et al.

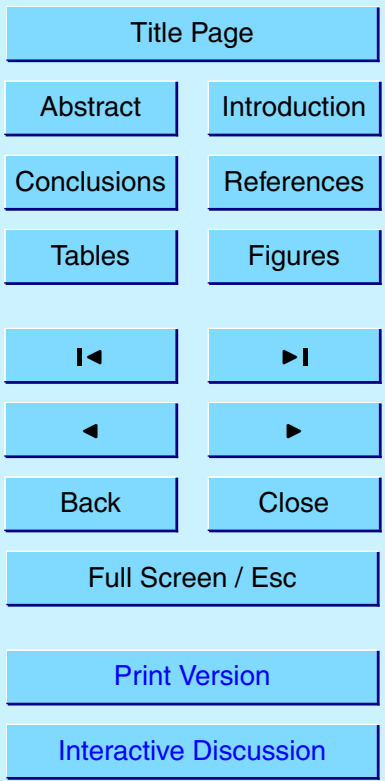

EGU 
plus diffuse) spectral irradiances throughout the wavelength domain 400-700 nm. Observed values (black symbols) were provided by the INPE/CPTEC team participating in the LBA-RACCI-SMOCC campaign. Modeled values were obtained as explained above, by neglecting (blue) or taking into account (red symbols) the role of aerosol par5 ticles in scattering and absorbing solar radiation. Rapid variations of observed values can be associated with the occurrence of water clouds near the sun apparent disk, obscuring the latter (smaller values) or allowing sharp increases in scattered diffuse radiation (greater values). Smooth variations of observed values can be associated with sun position, and changes in aerosol loading, aerosol properties, or occurrence of 10 ice clouds. Modeled values exhibit smooth variations in time because no water clouds were included in the computations; moreover, the computations neglected the occurrence of ice clouds. With the inclusion of biomass burning aerosols associated with moderate to high optical depths, direct radiation is severely reduced and diffuse radiation is enhanced; because some scattered radiation returns to space and also because some absorption takes place into the layers containing particles, the resulting global irradiance at the ground must be smaller than that without such particles. Hence, the red symbols are always below the blue symbols in Fig. 9. This figure suggests that our radiative transfer computations are reliable. In spite of absence of observations of actinic fluxes during the LBA-RACCI-SMOCC campaign, whose availability would validate our computations, we assume after Fig. 9 that coupling of Procopio et al.'s aerosol model to the TUV radiative transfer model is a promising strategy for evaluating the influence of biomass burning aerosol on photolysis rates.

Some important processes contributing for the production and loss of ozone and radicals' formation and to what extent they are affected by the presence of the biomass burning aerosol particles in the atmosphere were explored. Figure 10 shows the vertical profile of the percentage deviation of the photolysis rates for different chemical processes and atmospheric conditions when the aerosol effect is considered and neglected, respectively. The photolysis rates are calculated from the actinic flux spectrum, the absorption cross-section, and the quantum yield, which may vary as a function of

ACPD

$5,9325-9353,2005$

Impact of smoke aerosol on the photolysis rates

L. M. M. Albuquerque et al.

Title Page

Abstract Introduction

Conclusions

References

Tables

Figures

14

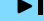

4

Back

Close

Full Screen / Esc

Print Version

Interactive Discussion 
temperature and pressure. The molecular data were updated in this study (Orlando et al., 1999a, b, c). Photodissociation of $\mathrm{NO}_{2}$ producing $\mathrm{O}\left({ }^{3} \mathrm{P}\right)$ oxygen atom leads to the only in situ chemical source of ozone in the troposphere and thus is an extremely important reaction. Nitric acid photolysis process is a source of the hydroxyl radical, $5 \mathrm{OH}$ and $\mathrm{NO}_{2}$ through $350 \mathrm{~nm}$. The photochemistry of the ozone is very complex, as the relatively weak chemical bonds in ozone allow excited states of the $\mathrm{O}$ and $\mathrm{O}_{2}$ photoproducts to be accessed. For atmospheric considerations, the key channel is the one that produce $\mathrm{O}\left({ }^{1} D\right)$, that is, the one that leads to $\mathrm{OH}$ production. Formaldehyde photolysis is a significant source of free radicals in the troposphere and produce molecular 10 hydrogen, $\mathrm{H}_{2}$, the second most abundant reactive trace gas in the troposphere, after methane. Typically, the photolysis rates are reduced by around $70 \%$ in the presence of smoke aerosol near ground level. However, above the smoke layer (around $3.5 \mathrm{~km}$ ), the photolysis processes increase by about $40 \%$ with an aerosol optical thickness $(500 \mathrm{~nm})$ of 1.94 , associated with the aerosol backscattering solar radiation.

15 Figure 11 shows the time profile of ozone predicted by MOZART-2 mechanism in a OZIPR simple trajectory model simulation of a particular day (19 September 2002) in Rôndonia, including (light blue line) and neglecting (red) the aerosol load concentration and observed (dark blue line) at surface level. The PAR surface irradiances $\left(\mathrm{Wm}^{-2}\right)$ are also shown in the same figure to track the diurnal solar cycle. Ozone formation begins some instants after the radiation goes up. The measured ozone as well as modeled ozone (including the aerosol effect) shows an increase following maximum concentration value at the end of the day when the biomass burning events are more intense, around 17:00 UTC. The chemical mechanism reproduces quite well the ozone formation along the diurnal cycle. The observed time of the maximum of the ozone concentration at around 20:00 UTC, although underestimated, is reproduced by the model. After that, following the decrease of solar radiation availability, photochemistry processes fall smoothly until the next day. During biomass burning events, with high loadings of biomass burning emissions, the nighttime ozone average concentrations reach around $15 \mathrm{ppb}$, and the model was able to describe correctly these reductions on

Impact of smoke aerosol on the photolysis rates

L. M. M. Albuquerque et al.

Title Page

Abstract Introduction

Conclusions

References

Tables Figures
14

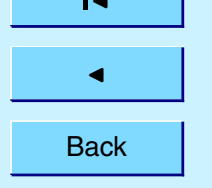

$\checkmark$

Close
Full Screen / Esc

Print Version

Interactive Discussion

EGU 
the ozone concentration in the absence of radiation. On the other side, the high value of ozone concentration, around $150 \mathrm{ppb}$, was obtained by the model in the presence of the same high smoke emissions, but representing clean atmosphere conditions (no aerosols particles) from the radiative point of view.

\section{5. Conclusions}

This study uses data from the LBA-RACCI-SMOCC campaign conducted during the dry-to-wet transition season (September-November 2002) in a pasture site in Rondônia, SW Amazonia, to evaluate the sensitivity of photolysis rates calculation to the direct radiative effect of smoke aerosol particles. The impact of this effect on 10 the chemical species production and loss in the gaseous phase, such as ozone, via photochemistry process was tested.

The TUV model, with the addition of a dynamical smoke aerosol model, results in PAR irradiances in good agreement with the measured values, in line with the initial hypothesis of substantial actinic flux attenuation near ground level due the smoke 15 aerosols. For the highest value of AOT along this day $(2.3 \pm 1.1)$ this attenuation reached $70 \%$.

The smoke aerosol absorbing character is apparent in the spectral range around $400 \mathrm{~nm}$, favoring some important photochemistry process occurring in this spectral range. The photolysis rates are typically reduced by around $70 \%$ near the ground.

20 Above the smoke layer, the photolysis process tends to increase by about $40 \%$. These results indicate a direct influence of the smoke particles in the atmospheric chemistry. Smoke aerosol particles change the visible and UV radiation flux and the spectral irradiance and, thereby, directly have an effect on the photochemistry. The production of $\mathrm{OH}$ and others radicals are affected and ozone formation is suppressed.

25 Considering the photolysis rates recalculated taking into account the presence of smoke in the aerosol layer, the modeled diurnal cycle of ozone follows closely the observations. On the other hand, when the attenuation of solar radiation due the smoke
ACPD

5, 9325-9353, 2005

Impact of smoke aerosol on the photolysis rates

L. M. M. Albuquerque et al.

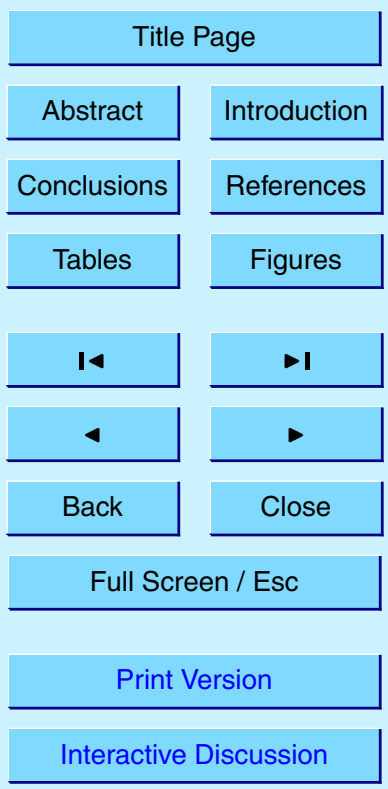

EGU 
aerosol particles are not taken into account, the diurnal cycle of the modeled ozone

presents a different shape. The production of the ozone is strongly favored and the ozone concentration reaches a peak value of almost $150 \mathrm{ppb}$ against observed values of $70 \mathrm{ppb}$. And, more importantly, the consumption of the ozone in the absent of solar 5 light does not reproduced properly the low values of night-time ozone concentrations typically observed. This comparison highlights the importance of describing properly the photochemistry due to the presence of smoke.

Acknowledgements. This work was carried out within the frame work of the Smoke, Aerosols, Clouds, Rainfall, and Climate (SMOCC) project, a European contribution to the Large-Scale

10 Biosphere-Atmosphere Experiment in Amazonia (LBA). It was financially supported by the Fundação de Amparoà Pesquisa do Estado de São Paulo (FAPESP) which supported a research scholarship 02/09732-0 of the first author. It was further supported by the Environmental and Climate Program of the European Commission (contract No. EVK2-CT-2001-00110 SMOCC), the Max Planck Society (MPG), and the Conselho Nacional de Desenvolvimento 15 Científico (Instituto do Milênio LBA). We thank all members of the LBA-SMOCC and LBARACCI Science Teams for their support during the field campaign, especially A. C. Ribeiro, M. A. L. Moura, and J. von Jouanne. We also thank S. Madronich for making available TUV 4.2, helpful discussions with T. S. Dibble and L. Emmons, G. S. Tonnesen for the OZIPR revised version.

\section{References}

Andreae, M. O., Rosenfeld, D., Artaxo, P., Costa, A. A., Frank, G. P., Longo, K. M., and SilvaDias, M. A. F.: Smoking rain clouds over the Amazon, Science, 303, 1337-1342, 2004.

Bais, A. F., Madronich, S., Crawford, J., Hall, S. R., Mayer, B., van Weele, M., Lenoble, J., Calvert, J. G., Cantrell, C. A., Shetter, R. E., Hofzumahaus, A., Koepke, P., Monks, P. S., Frost, G., McKenzie, R., Krotkov, N., Kylling, A., Swartz, W. H., Lloyd, S., Pfister, G., Martin, T.J., Roeth, E. P., Griffioen, E., Ruggaber, A., Krol, M., Kraus, A., Edwards, G. D., Mueller, M., Lefer, B. L., Johnston, P., Schwander, H., Flittner, D., Gardiner, B. G., Barrick, J., and Schmitt, R.: International Photolysis Frequency Measurement and Model Intercomparison (IPMMI): Spectral actinic solar flux measurements and modeling, J. Geophys. Res.-Atmos. 108, D16, 8543, doi:10.1029/2002JD002891, 2003.

\section{Impact of smoke aerosol on the photolysis rates}

L. M. M. Albuquerque et al.

Title Page

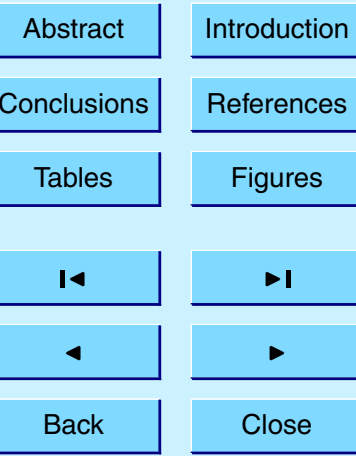

Full Screen / Esc

Print Version

Interactive Discussion 
Claeys, M., Graham, B., Vas, G., Wang, W., Vermeylen, R., Pashynska, V., Cafmeyer, J., Guyon, P., Andreae, M. O., Artaxo, P., and Maenhaut, W.: Formation of Secondary Organic Aerosols Through Photooxidation of Isoprene, Science, 303, 1173-1176, 2004.

Demerjian, K. L., Schere, K. L., and Peterson, J. T.: Theoretical Estimates of Actinic (spherical integrated) Flux and Photolytic Rate Constants of Atmospheric Species in the Lower Troposphere, Adv. Environ. Sci. Tech., 10, 369-459, 1980.

Fearnside, P. M., Laurance, W. F., Albernaz, A. K. M., Vasconcelos, H. L., and Ferreira, L. V.: A delicate balance in Amazonia - Response, Science, 307, 5712, 1045-1045, 2005.

Feister, U. and Grewe, R.: Spectral Albedo Measurements in the UV and Visible Region Over Different Types of Surfaces, Photochem. Photobiol., 62, 4, 736-744, 1995.

Filyushkin, V. V., Madronich, S., Brasseur, G. P., and Petropavlovskikh, I. V.,: Fast 2-Stream Method for Computing Diurnal - Mean Actinic Flux in Vertically Inhomogeneous Atmospheres, J. Atmos. Sci., 51, 8, 1077-1088, 1994.

Freitas, S., Longo, K., Silva Dias, M. A. F., Silva Dias, P. L., Chatfield, R., Prins, E., Artaxo, O., 15 Grell, G., and Recuero, F.: Monitoring the transport of biomass burning emissions in South America, Environmental Fluid Mechanics, 5, 135-167, 2005.

Früh, B., Trautmann, T., Wendisch, M., and Keil, A.: Comparison of Observed and Simulated $\mathrm{NO}_{2}$ Photodissociation Rates in Boundary Layer Clouds Using Detailed Microphysical Model Input, J. Geophys. Res., 105, 9843-9857, 2000a.

20 Früh, B., Trautmann, T., and Wendisch, M.: Measurement Based $\mathrm{J}\left(\mathrm{NO}_{2}\right)$ Sensitivity in a Cloudless Atmosphere Under Low Aerosol Loading and High Solar Zenith Angle Conditions, Atmos. Environ., 34, 5249-5254, 2000b.

Graham, B., Guyon, P., Taylor, P. E., Artaxo, P., Maenhaut, W., Glovsky, M. M., Flagan, R. C., and Andreae, M. O.: Organic Compounds Present in the Natural Amazonian Aerosol: Characterization by Gas Chromatography-Mass Spectrometry, J. Geophys. Res.-Atmos., 108, D24, 4766, doi:10.1029/2003JD003990, 2003.

Graham, B., Guyon, P., Maenhaut, W., Taylor, P. E., Ebert, M., Matthias-Maser, S., MayolBracero, O. L., Godoi, R. H. M., Artaxo, P., Meixner, F. X., Moura, M. A. L., Rocha, C., Van Grieken, R., Glovsky, M. M., Flagan, R. C., and Andreae, M. O.: Composition and diurnal variability of the natural Amazonian aerosol, J. Geophys. Res.-Atmos., 108, D24, 4765, doi:10.1029/2003JD004049, 2003.

Greenberg, J. P., Guenther, A. B., Petron, G., Wiedinmyer, C., Vega, O., Gatti, L. V., Tota, J., and Fisch, G.: Biogenic VOC Emissions from Forested Amazonian Landscapes, Global

ACPD

$5,9325-9353,2005$

Impact of smoke aerosol on the photolysis rates

L. M. M. Albuquerque et al.

Title Page

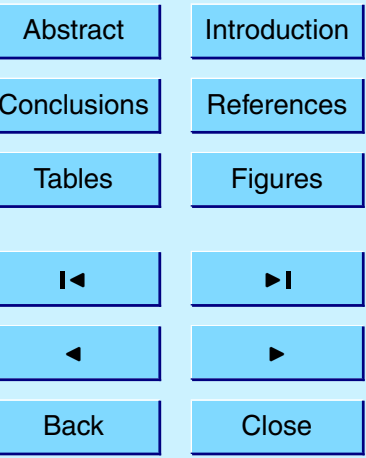

Full Screen / Esc

Print Version

Interactive Discussion 
Change Biology, 10, 5, 651-662, 2004.

Guyon, P., Graham, B., Beck, J., Boucher, O., Gerasopoulos, E., Mayol-Bracero, O. L., Roberts, G. C., Artaxo, P., and Andreae, M. O.: Physical Properties and Concentration of Aerosol Particles Over the Amazon Tropical Forest During Background and Biomass Burning Conditions,

$5 \quad$ Atmos. Chem. Phys., 3, 951-967, 2003, SRef-ID: 1680-7324/acp/2003-3-951.

Hofzumahaus, A., Lefer, B. L., Monks, P. S., Hall, S. R., Kylling, A., Mayer, B., Shetter, R. E., Junkermann, W., Bais, A., Calvert, J. G., Cantrell, C. A., Madronich, S., Edwards, G. D., Kraus, A., Muller, M., Bohn, B., Schmitt, R., Johnston, P., McKenzie, R., Frost, G. J., Griffioen, E., Krol, M., Martin, T., Pfister, G., Roth, E. P., Ruggaber, A., Swartz, W. H., Lloyd, S. A., and Van Weele, M.: Photolysis Frequency of O-3 to O(D-1): Measurements and Modeling During the International Photolysis Frequency Measurement and Modeling Intercomparison (IPMMI), J. Geophys. Res.-Atmos., 109, D8, S90, doi:10.1029/2003JD004333, 2004.

Holben, B. N., Eck, T. F., Slutsker, I., et al.: AERONET - A federated instrument network and data archive for aerosol characterization, Remote Sens. Eviron., 66, 1-15, 1998.

Horowitz, L. W., Walters, S., Mauzerall, D. L., Emmons, L. K., Rasch, P. J., Granier, C., Tie, X., Lamarque, J.-F., Schultz, M. G., and Brasseur, G. P.: A global simulation of tropospheric ozone and related tracers: Description and evaluation of MOZART, version 2, J. Geophys. Res., 108, D24, 4784, doi:10.1029/2002JD002853, 2003.

Horowitz, A., Meller, R., and Moortgat, G. K.: The UV-VIS Absorption Cross Sections of the Alpha-Dicarbonyl Compounds: Pyruvic acid, Biacetyl and Glyoxal, J. Photochem. and Photobio. A-Chem., 146(1-2), 19-27, 2001.

Junkermann, W., Bruhl, C., Perner, D., Eckstein, E., Trautmann, T., Fruh, B., Dlugi, R., Gori, T., Ruggaber, A., Reuder, J., Zelger, M., Hofzumahaus, A., Kraus, A., Rohrer, F., Bruning, D., Moortgat, G., Horowitz, A., and Tadic, J.: Actinic Radiation and Photolysis Processes in the Lower Troposphere: Effect of Clouds and Aerosols, J. Atmos. Chem., 42, 1, 413-441, 2002.

Kesselmeier, J., Kuhn, U., Rottenberger, S., Biesenthal, T., Wolf, A., Schebeske, G., Andreae, M. O., Ciccioli, P., Brancaleoni, E., Frattoni, M., Oliva, S. T., Botelho, M. L., Silva, C. M. A., and Tavares, T. M.: Concentrations and Species Composition of Atmospheric Volatile Organic Compounds (VOCs) as Observed During the Wet and Dry Season in Rôndonia (Amazonia), J. Geophys. Res.-Atmos., 107, D20, 8053, doi:10.1029/2000JD000267, 2002.

Kirkman, G. A., Gut, A., Ammann, C., Gatti, L. V., Cordova, A. M., Moura, M. A. L., Andreae, M. O., and Meixner, F. X.: Surface Exchange of Nitric Oxide, Nitrogen Dioxide, and
ACPD

5, 9325-9353, 2005

Impact of smoke aerosol on the photolysis rates

L. M. M. Albuquerque et al.

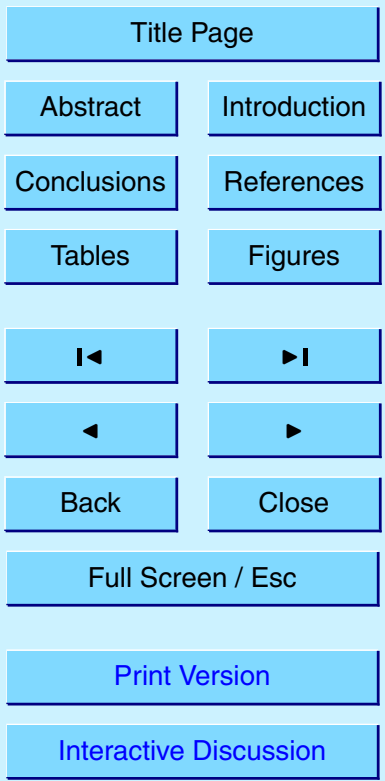

EGU 
Ozone at a Cattle Pasture in Rôndonia, Brazil, J. Geophys. Res.-Atmos., 107, D20, 8083, doi:10.1029/2001JD000523, 2002.

Lefer, B. L., Shetter, R. E., Hall, S. R., Crawford, J. H., and Olson, J. R.: Impact of Clouds and Aerosols on Photolysis Frequencies and Photochemistry During TRACE-P: 1. Analysis

$5 \quad$ Using Radiative Transfer and Photochemical Box Models, J. Geophys. Res.-Atmos., 108, D21, 8821, doi:10.1029/2002JD003171, 2003.

Madronich, S.: Photodissociation in the atmosphere, 1. Actinic flux and the effects of ground reflections and clouds, J. Geophys. Res., 92, 9740-9752, 1987.

Neckel, H. and Labs, D.: Improved Data of Solar Spectral Irradiance from 0.33 to $1.25 \mu \mathrm{m}$, Solar Phys., 90, 205-258, 1984.

Orlando, J. J.: Temperature dependence of the rate coefficients for the reaction of chlorine atoms with chloromethanes, Int. J. Chem. Kinet., 31, 515-524, 1999a.

Orlando, J., Tyndall, G., and Paulson, S.: Mechanism of the $\mathrm{OH}$-initiated oxidation of methacrolein, Geophys. Res. Lett., 26, 2191-2194, 1999b.

Orlando, J., Tyndall, G., Fracheboud, J.-M., Estupiñan, E., Haberkorn, S., and Zimmer, A.: The rate and mechanism of the gas-phase oxidation of hydroxyacetone, Atmos. Environ., 33, 1621-1629, 1999c.

Olson, J. R., Crawford, J. H., Chen, G., Fried, A., Evans, M. J., Jordan, C. E., Sandholm, S. T., Davis, D. D., Anderson, B. E., Avery, M. A., Barrick, J. D., Blake, D. R., Brune, W. H., Eisele, F. L., Flocke, F., Harder, H., Jacob, D. J., Kondo, Y., Lefer, B. L., Martinez, M., Mauldin, R. L., Sachse, G. W., Shetter, R. E., Singh, H. B., Talbot, R. W., and Tan, D.: Testing Fast Photochemical Theory During TRACE-P Based on Measurements of $\mathrm{OH}, \mathrm{HO}_{2}$, and $\mathrm{CH}_{2} \mathrm{O}$, J. Geophys. Res.-Atmos., 109, D15, D15S10, doi:10.1029/2003JD004278, 2004.

Peters, W., Krol, M. C., Fortuin, J. P. F., Kelder, H. M., Thompson, A. M., Becker, C. R., Lelieveld, 25 J., and Crutzen, P. J.: Tropospheric Ozone Over a Tropical Atlantic Station in the Northern Hemisphere: Paramaribo, Surinam, Tellus Series B-Chemical and Physical Meteorology, 56, 1, 21-34, 2004.

Procopio, A. S., Remer, L. A., Artaxo, P., Kaufman, Y. J., and Holben, B. N.: Modeled Spectral Optical Properties for Smoke Aerosols in Amazonia, Geophys. Res. Lett., 30, 24, 2265, doi:10.1029/2003GL018063, 2003.

Procopio, A. S., Artaxo, P., Kaufman, Y. J., Remer, L. A., Schafer, J. S., and Holben, B. N.: Multiyear Analysis of Amazonian Biomass Burning Smoke Radiative Forcing of Climate, Geophys. Res. Lett., 31, 3, L3108-L3112, 2004.

\section{Impact of smoke aerosol on the photolysis rates}

L. M. M. Albuquerque et al.

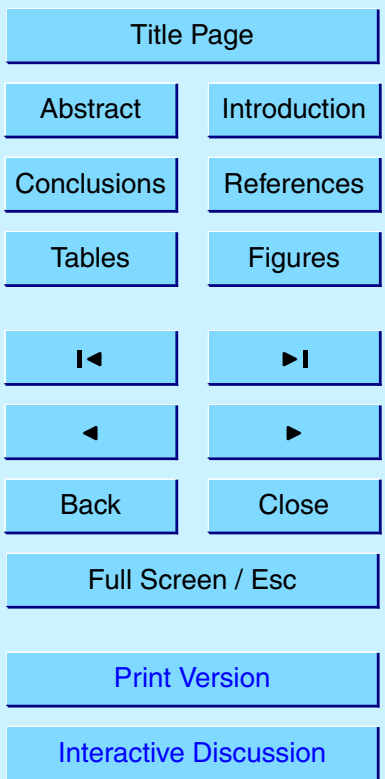

EGU 
Ruggaber, A., Dlugi, R., and Nakajima, T.: Modeling of Radiation Quantities and Photolysis Frequencies in the Troposphere, J. Atmos. Chem., 18, 171-210, 1994.

Seinfeld, J. H. and Pandis, S. N.: Atmospheric Chemistry and Physics: From Air Pollution to Climate Change, Wiley, New York, 724-743, 1998.

5 Tie, X. X., Madronich, S., Walters, S., Zhang, R. Y., Rasch, P., and Collins, W.: Effect of Clouds on Photolysis and Oxidants in the Troposphere, J. Geophys. Res.-Atmos., 108, D20, 4642, doi:10.1029/2003JD003659, 2003.

Thompson, A. M., Witte, J. C., McPeters, R. D., Oltmans, S. J., Schmidlin, F. J., Logan, J. A., Fujiuara, M., Kirchhoff, V. W. J. H., Posny, F., Coetzee, G. J. R., Hoegger, B., Kawakami, S., Ogawa, T., Johnson, B. J., Vomel, H., and Labow, G.: Southern Hemisphere additional ozonesondes (SHADOZ) 1998-2000 tropical ozone climatology 1, Comparison with total ozone mapping spectrometers (TOMS) and ground-based measurements, J. Geophys. Res.Atmos., 108, D2, 8238, doi:10.1029/2001JD000967, 2003.

Tonnesen, G. S. and Dennis, R. L.: Analysis of Radical Propagation Efficiency to Assess Ozone 15 Sensitivity to Hydrocarbons and $\mathrm{NO}_{x}$, Part 1: Local Indicators of Odd Oxygen Production Sensitivity, J. Geophys. Res., 105, 9213-9225, 2000.

Trentmann, J., Fruh, B., Boucher, O., Trautmann, T., and Andreae, M. O.: Three-Dimensional Solar Radiation Effects on the Actinic Flux Field in a Biomass-Burning Plume, J. Geophys. Res.-Atmos., 108, D17, 4558, doi:10.1029/2003JD003422, 2003.

20 Tsay, S. C., King, M. D., Arnold, G. T., and Li, J. Y.: Airborne spectral measurements of surface anisotropy during SCAR-B, J. Geophys. Res., 103, 31 943-31 954, 1998.

Van Hoosier, M. E.: The ATLAS-3 solar spectrum, available via anonymous ftp (ftp://susim.nrl. navy.mil/pub/atlas3), 1996.

World Meteorological Organization (WMO): World Climate Research Programme: A preliminary cloudless standard atmosphere for radiation computation, Rep. WCP-112, WMO/TD24, 53 pp., Geneva, 1986.

Weavers, L. K., Ling, F. H., and Hoffmann, M. R.: The Combination of Sonolysis and Ozonolysis for Aromatic Compound Degradation, Environ. Sci. Technol., 32, 2727-2733, 1998.

Yamasoe, M., von Randow, C., and Manzi, A.: Effect of Smoke on the Transmissivity of Pho30 tosynthetically Active Radiation Inside the Canopy, Atmos. Chem. Phys. Discuss., 5, 59095934, 2005, SRef-ID: 1680-7375/acpd/2005-5-5909.

\section{Impact of smoke aerosol on the photolysis rates}

L. M. M. Albuquerque et al.

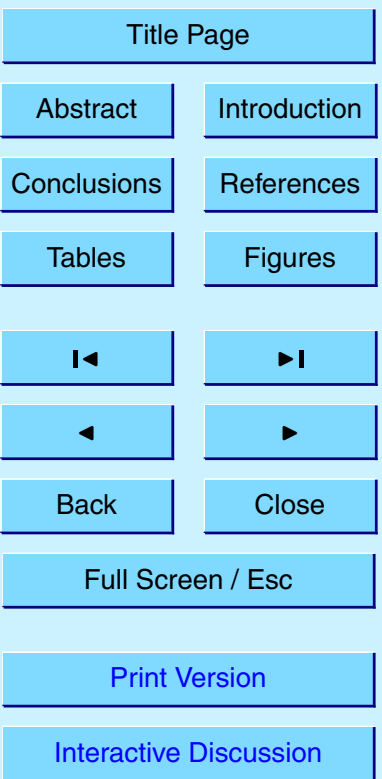




\section{ACPD}

5, 9325-9353, 2005

Impact of smoke aerosol on the photolysis rates

Table 1. Aerosol extinction coefficients at $550 \mathrm{~nm}$ following WMO (1986).

L. M. M. Albuquerque et al.

\begin{tabular}{rlll}
\hline$\varepsilon_{0}\left(\mathrm{~km}^{-1}\right)$ & Continental & Background & Upper \\
\hline $5-12 \mathrm{~km}$ & 0.0025 & & \\
$12-30 \mathrm{~km}$ & & $2.18 \times 10^{-4}$ & \\
$30-35 \mathrm{~km}$ & & $3.32 \times 10^{-5}$ & $2.45 \times 10^{-5}$ \\
$35-40 \mathrm{~km}$ & & & $8.00 \times 10^{-5}$ \\
$40-45 \mathrm{~km}$ & & $4.02 \times 10^{-6}$ \\
$45-50 \mathrm{~km}$ & & $2.10 \times 10^{-6}$ \\
$50-70 \mathrm{~km}$ & & $1.60 \times 10^{-7}$ \\
$70-100 \mathrm{~km}$ & & $9.30 \times 10^{-10}$ \\
\hline
\end{tabular}

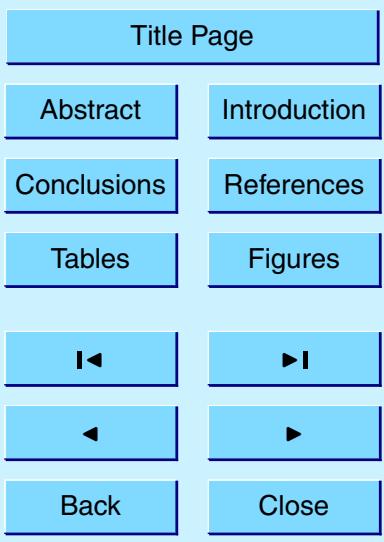

Full Screen / Esc

Print Version

Interactive Discussion

EGU 


\section{ACPD}

$5,9325-9353,2005$

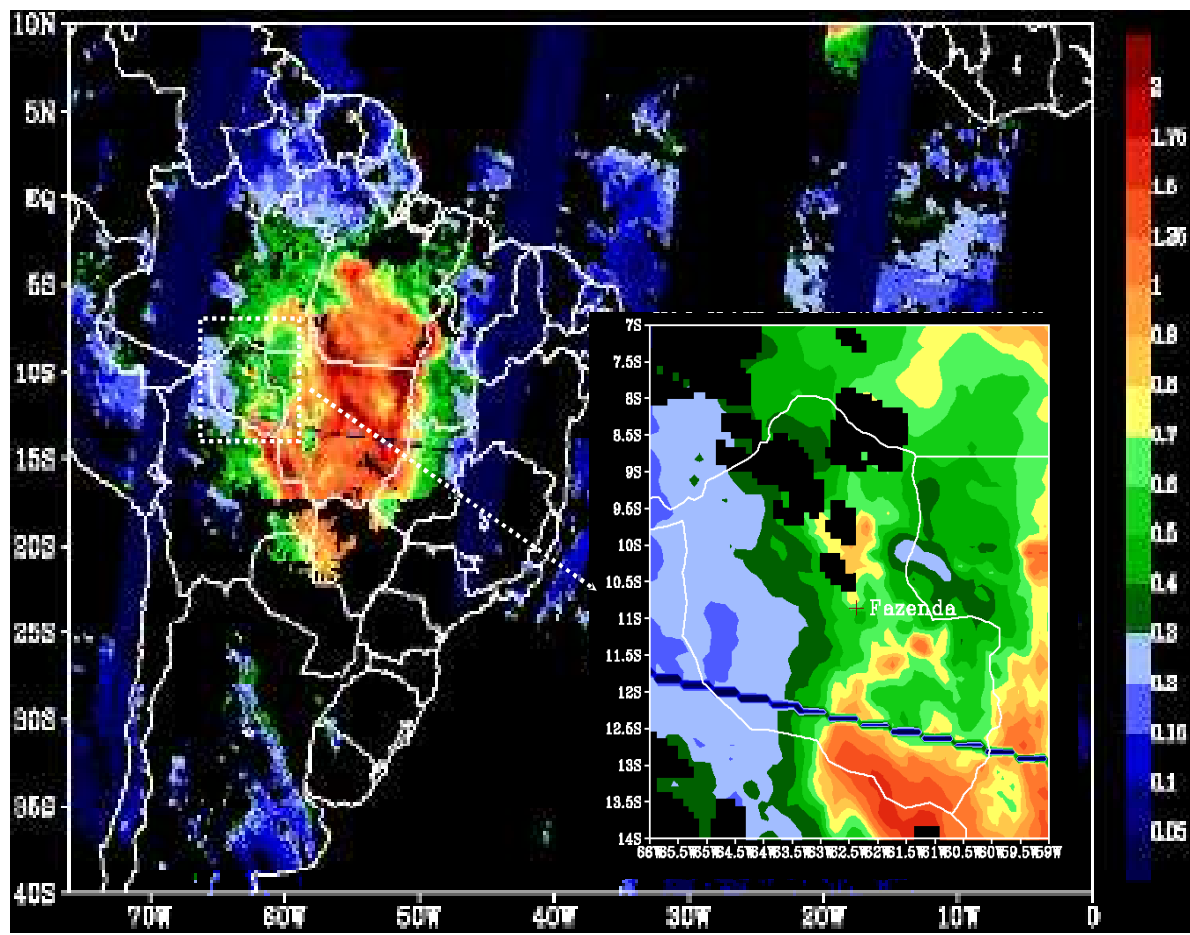

\section{Impact of smoke aerosol on the photolysis rates}

L. M. M. Albuquerque et al.

Fig. 1. Map with aerosol optical thickness $(550 \mathrm{~nm})$ from MODIS-TERRA aerosol product over South America and a zoom over the Rôndonia State on 19 September 2002 around 14:00 UTC (http://modis-atmos.gsfc.nasa.gov/). 


\section{ACPD}

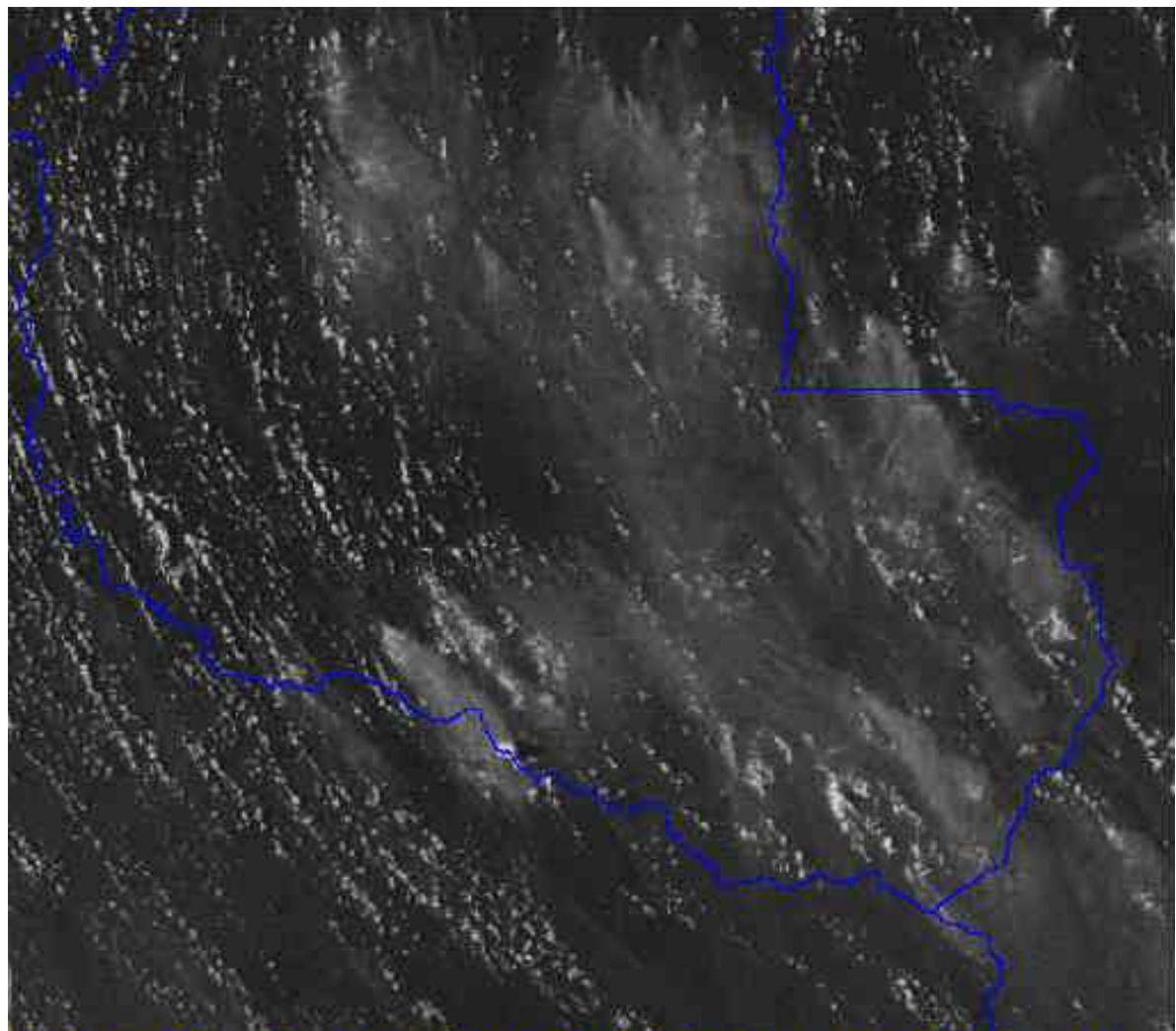

$5,9325-9353,2005$

Impact of smoke aerosol on the photolysis rates

L. M. M. Albuquerque et al.

\begin{tabular}{|c|c|}
\hline \multicolumn{2}{|c|}{ Title Page } \\
\hline Abstract & Introduction \\
\hline Conclusions & References \\
\hline Tables & Figures \\
\hline 14 & $\rightarrow 1$ \\
\hline 4 & $\triangleright$ \\
\hline Back & Close \\
\hline \multicolumn{2}{|c|}{ Full Screen / Esc } \\
\hline \multicolumn{2}{|c|}{ Print Version } \\
\hline Interactiv & iscussion \\
\hline
\end{tabular}

Fig. 2. GOES-8 visible image over Rondnia State on 19 September 2002 at 19:45 UTC showing several smoke plumes. The blue line shows the Rndonia State contour map. Source: Master Lab. IAG-USP (http://www.master.iag.usp.br). 


\section{ACPD}

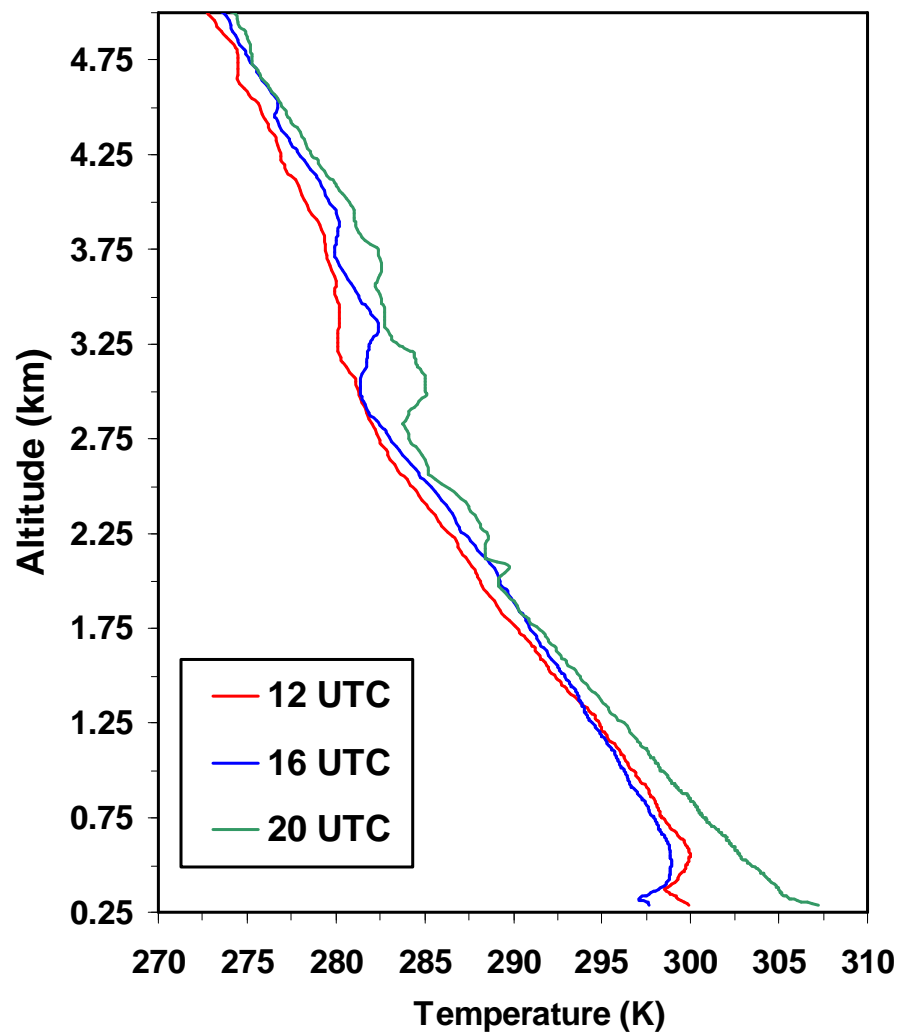

$5,9325-9353,2005$

Impact of smoke aerosol on the photolysis rates

L. M. M. Albuquerque et al.

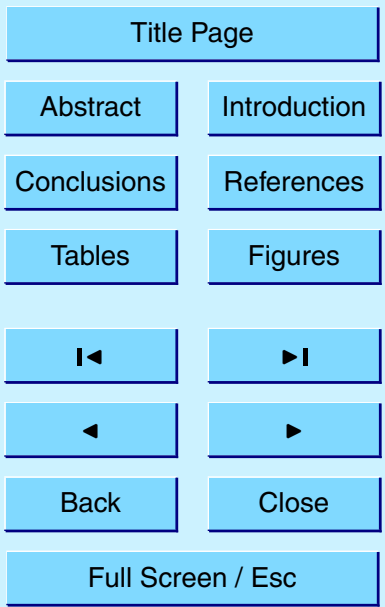

Fig. 3. Vertical profiles of temperatures on 19 September 2002 from Fazenda N. Senhora. site Print Version radiosondes during LBA-RACCI-SMOCC field experiment. 


\section{ACPD}

$5,9325-9353,2005$

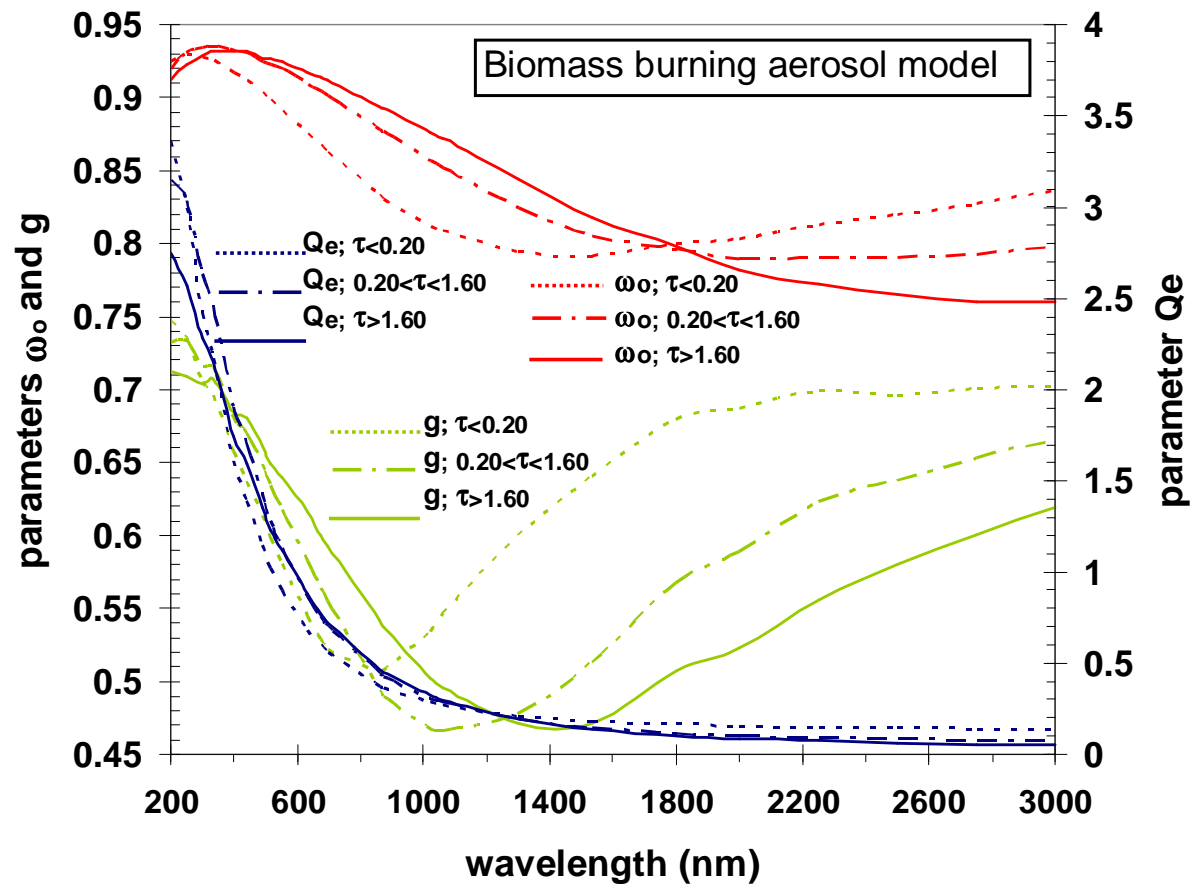

Impact of smoke aerosol on the photolysis rates

L. M. M. Albuquerque et al.

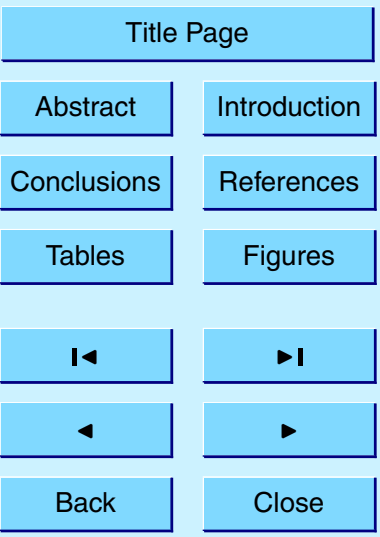

Fig. 4. Spectral smoke aerosol optical properties (single scattering albedo $\varpi_{0}$, asymmetry parameter of the phase function $g$ and extinction coefficient $Q_{e}$ ) as functions of the aerosol Full Screen / Esc optical thickness at $500 \mathrm{~nm}\left(\tau_{a}\right)$ derived from three years of AERONET data collected during the dry season in Amazonia (Procopio et al., 2003).

Print Version

Interactive Discussion 


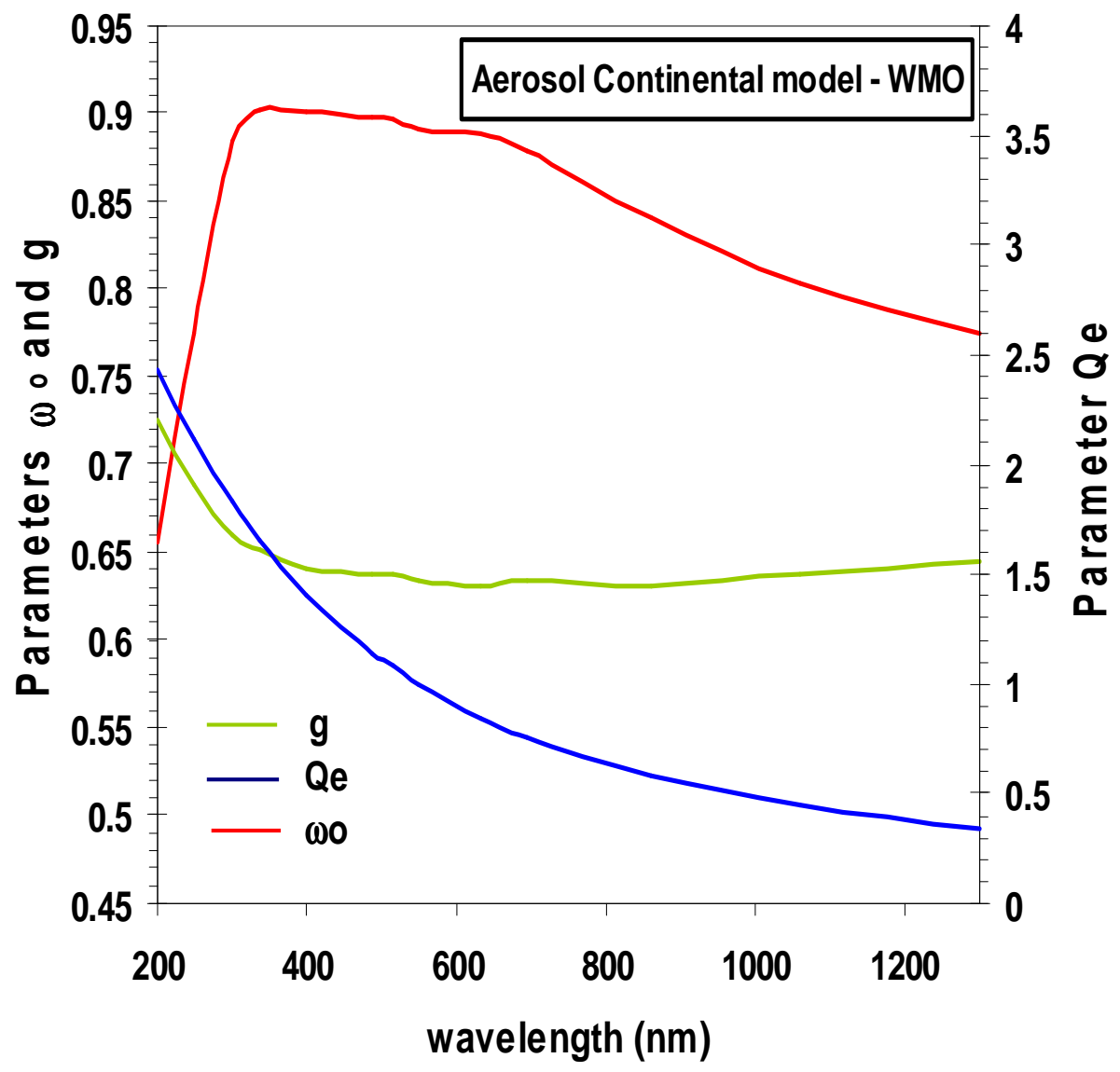

Fig. 5. Spectral continental aerosol optical properties (single scattering albedo $\varpi_{0}$, asymmetry parameter of the phase function $g$ and extinction coefficient $Q_{e}$ ) from WMO (1986).

\section{ACPD}

5, 9325-9353, 2005

Impact of smoke aerosol on the photolysis rates

L. M. M. Albuquerque et al.

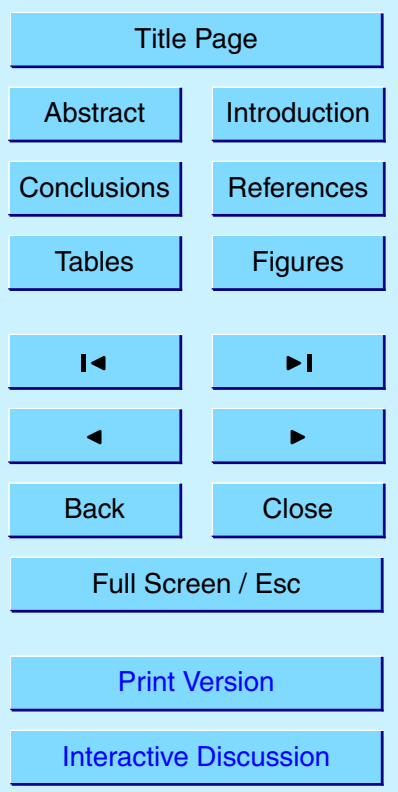




\section{ACPD}

$5,9325-9353,2005$

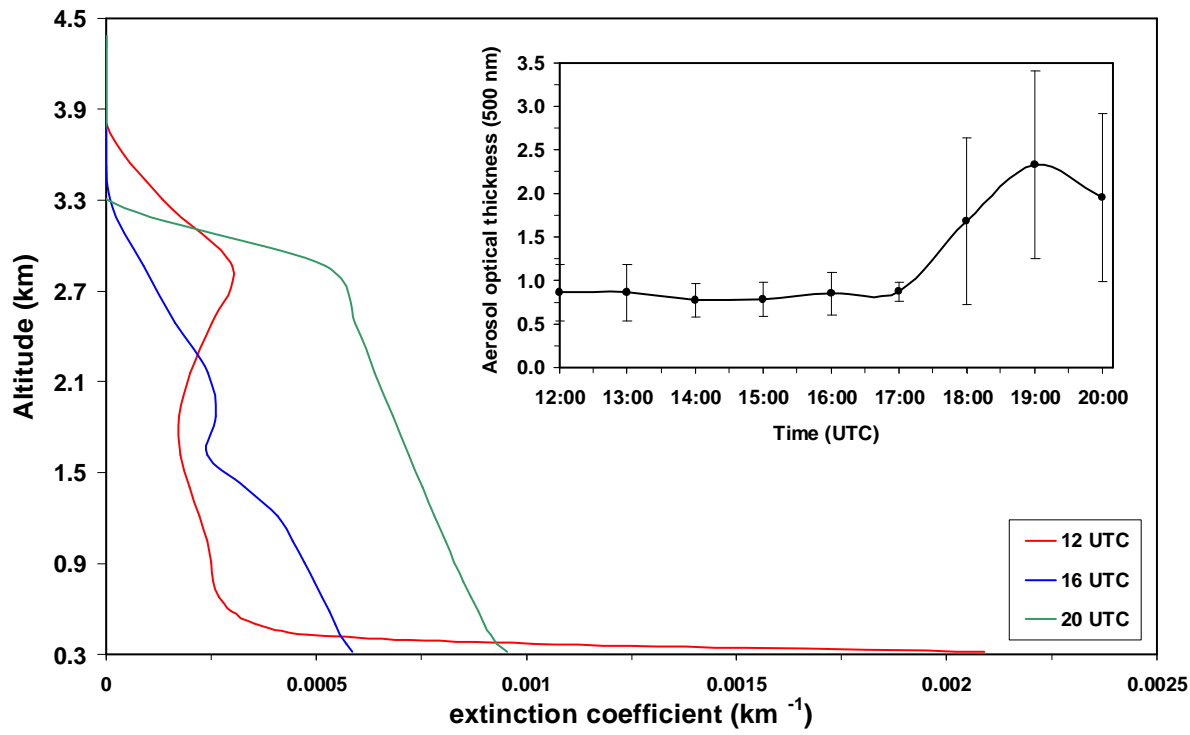

\section{Impact of smoke aerosol on the photolysis rates}

L. M. M. Albuquerque et al.

Fig. 6. The vertical profile of the biomass burning aerosol extinction $\left(\mathrm{km}^{-1}\right)$ in the boundary layer at 12:00, 16:00 and 20:00 UTC for 19 September 2002. The normalized vertical structure is from the CATT-BRAMS model and the column integrated aerosol optical depth is an average of the sunphotometer (AERONET and hazemeter) data available for different sites in the Rndonia State for this day and the error bars represent the standard deviation of the average (shown in the detail).

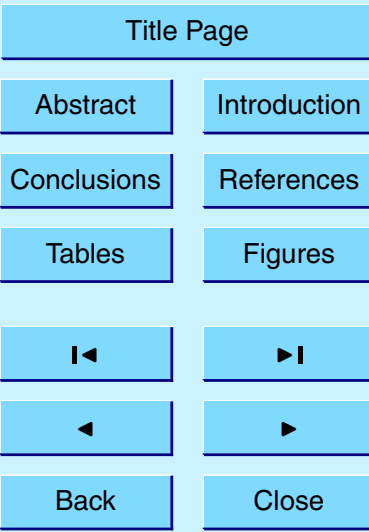

Full Screen / Esc

Print Version

Interactive Discussion 


\section{ACPD}

$5,9325-9353,2005$

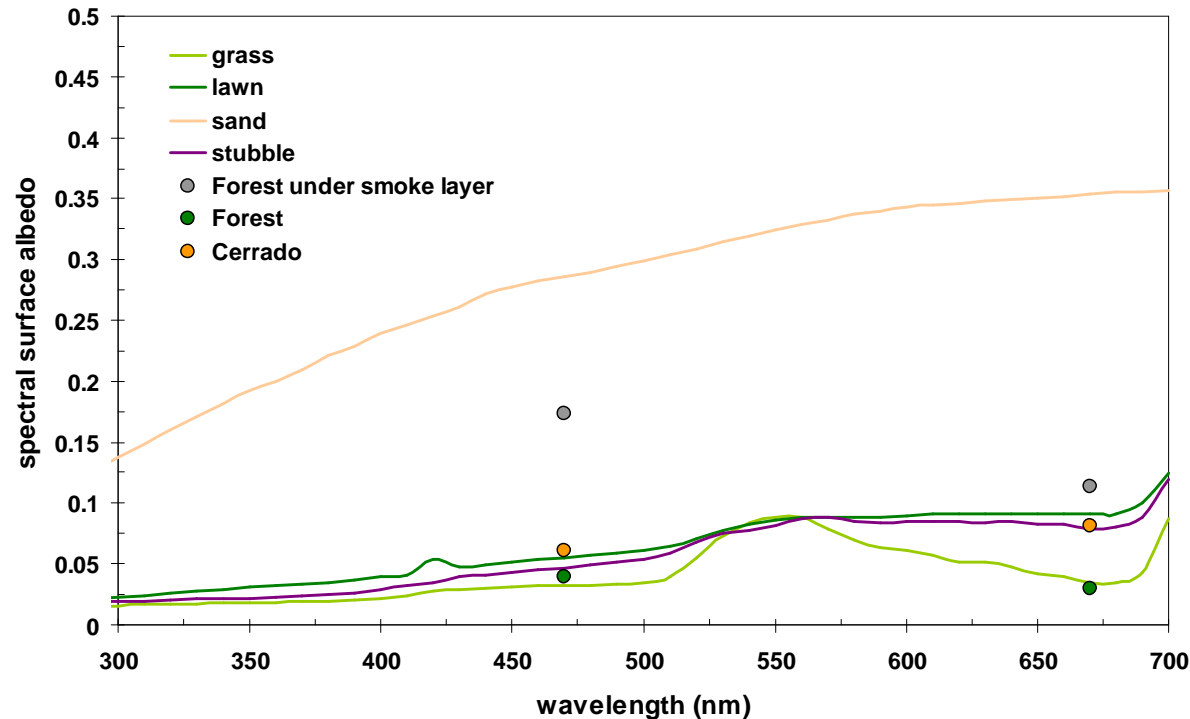

Impact of smoke aerosol on the photolysis rates

L. M. M. Albuquerque et al.

Fig. 7. Spectral albedo measured over different surfaces (grass, lawn, sand and stubble) by Feister (1995) and over forest, savanna (cerrado) and forest under smoke layer in the Amazon, Si-Chee et al. (1998).

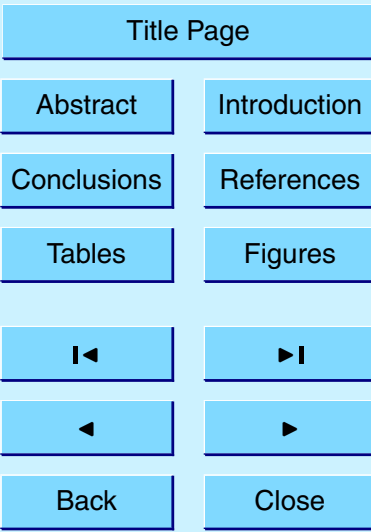

Full Screen / Esc

Print Version

Interactive Discussion 


\section{Wavelength $(\mathrm{nm})$}
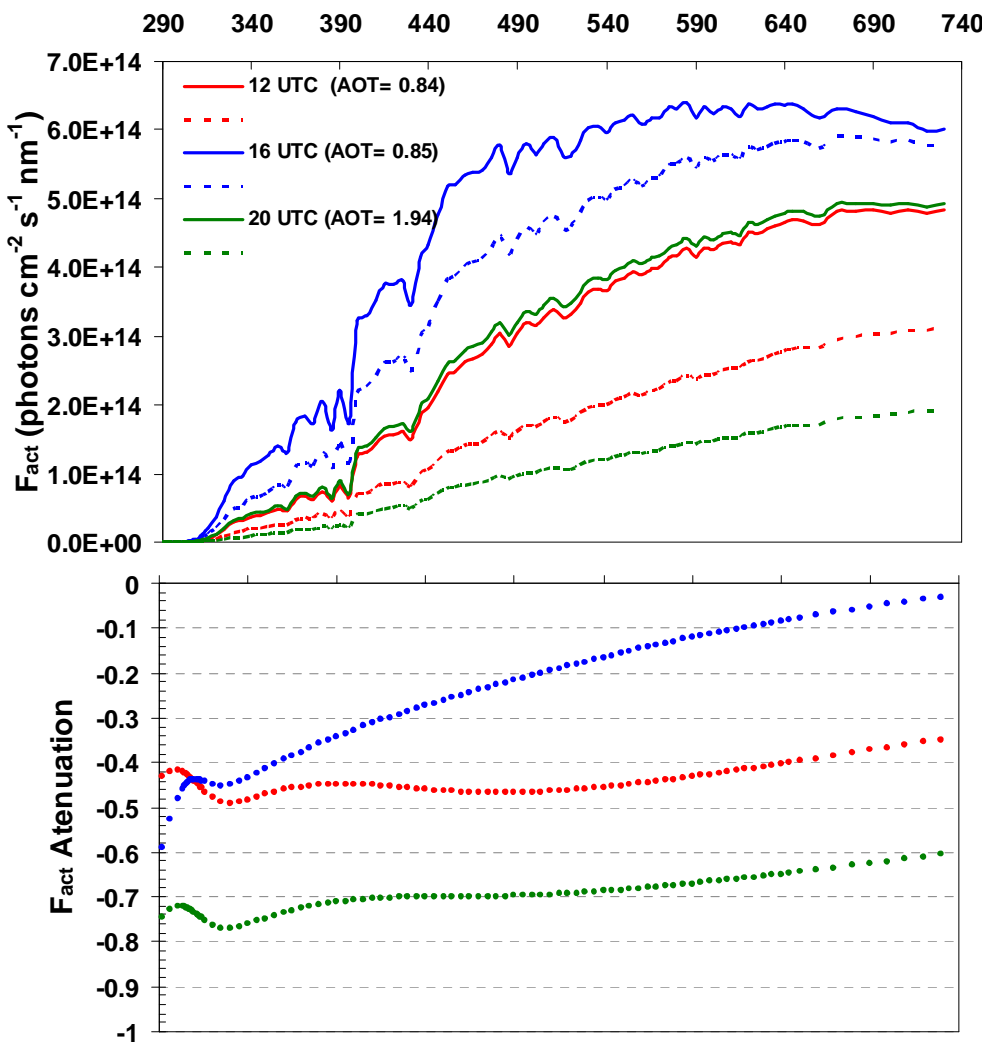

Fig. 8. (a) Actinic flux near ground level on 19 September 2002, in Rondônia at 12:00, 16:00 and 20:00 UTC (solar zenith angles of $61.66^{\circ}, 12.13^{\circ}$ and $60.06^{\circ}$ ). The dotted lines describe the simulation neglecting aerosol loading and the solid lines refer to the simulation taking the aerosol loading into account. (b) The ratios between the simulated values for the actinic flux with and without consideration of the aerosol presence at 12:00, 16:00 and 20:00 UTC.

\section{ACPD}

$5,9325-9353,2005$

Impact of smoke aerosol on the photolysis rates

L. M. M. Albuquerque et al.

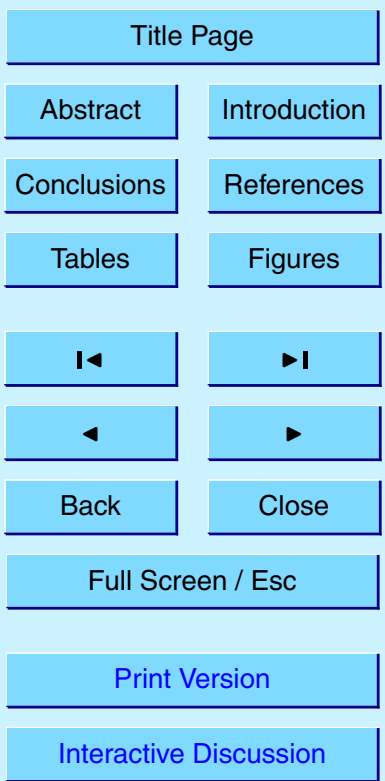




\section{ACPD}

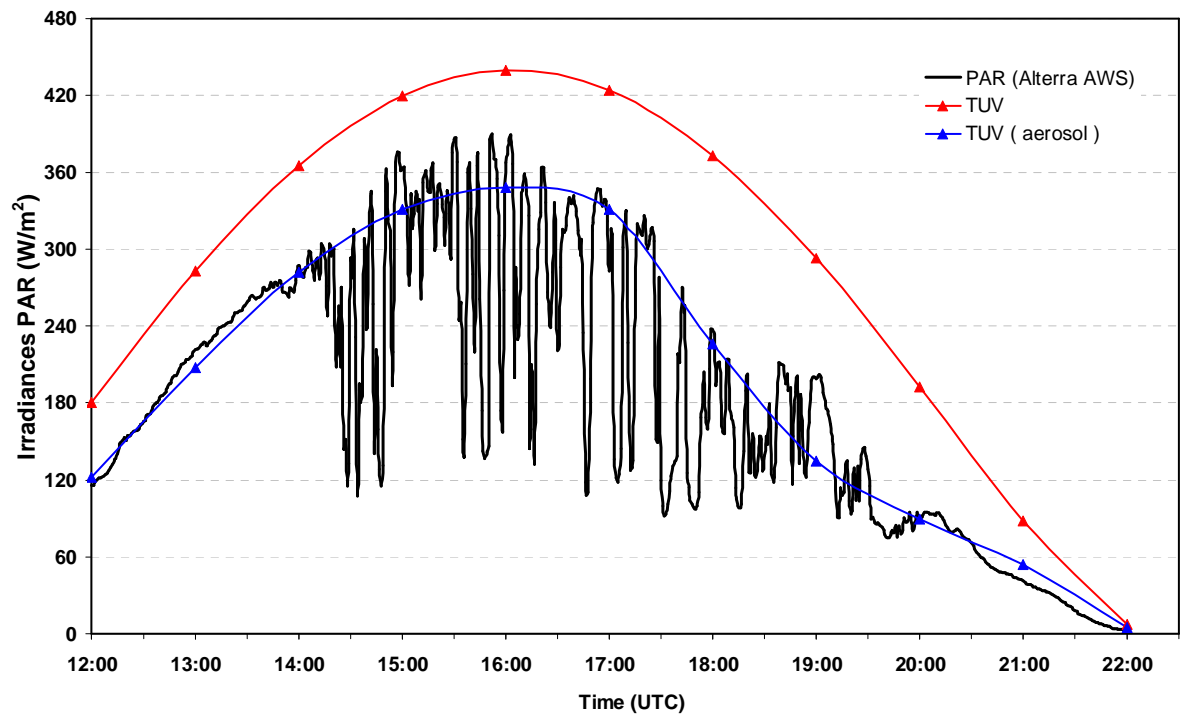

Fig. 9. PAR surface irradiances $\left(\mathrm{Wm}^{-2}\right)$ observed on 19 September 2002 in the Fazenda N. Senhora and the comparison with modeled irradiances by TUV model when including (blue line) and neglecting (red line) the aerosol load concentration.
$5,9325-9353,2005$

Impact of smoke aerosol on the photolysis rates

L. M. M. Albuquerque et al.

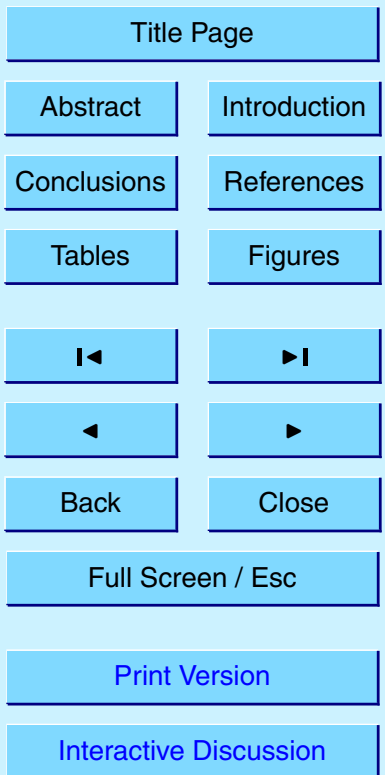



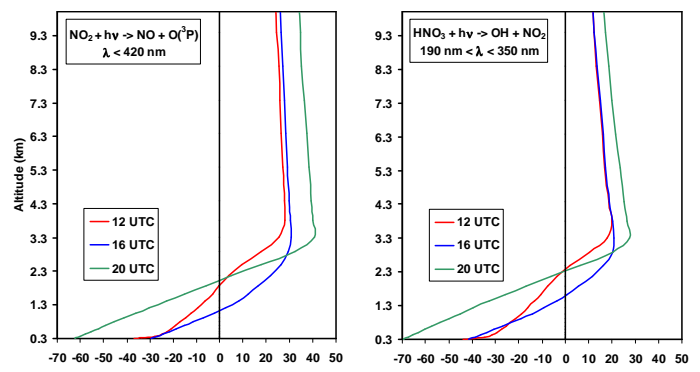

\section{ACPD}
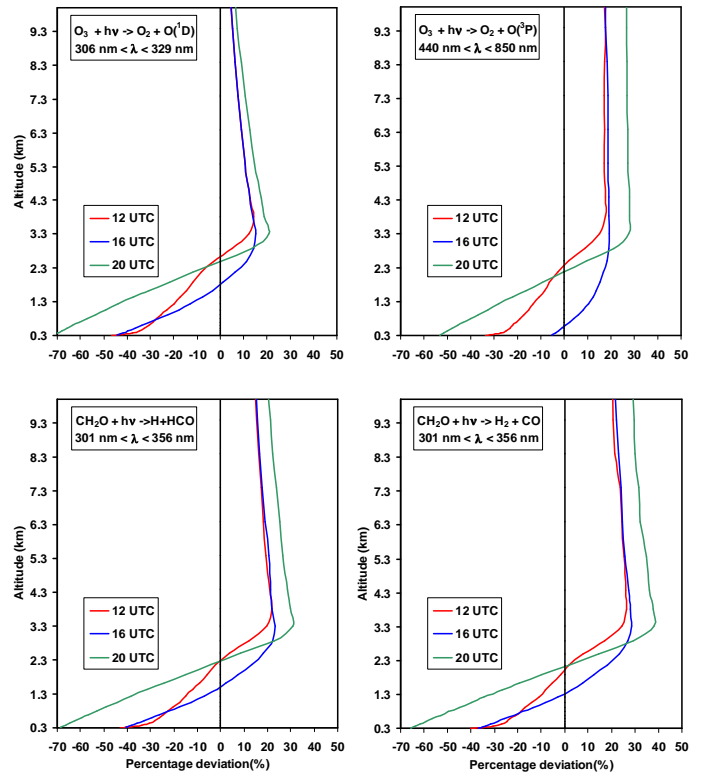

Fig. 10. Vertical profile of the percentage deviation of the photolysis rates for different chemical processes and atmospheric conditions when the aerosol radiative effect is considered and neglected.

5, 9325-9353, 2005

Impact of smoke aerosol on the photolysis rates

L. M. M. Albuquerque et al.

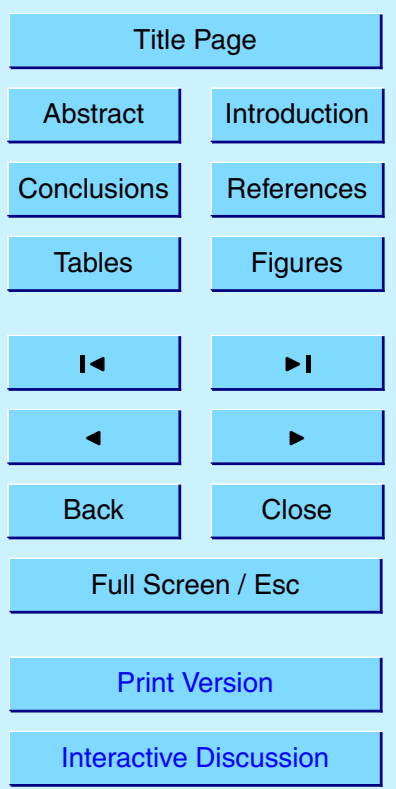

EGU 


\section{ACPD}

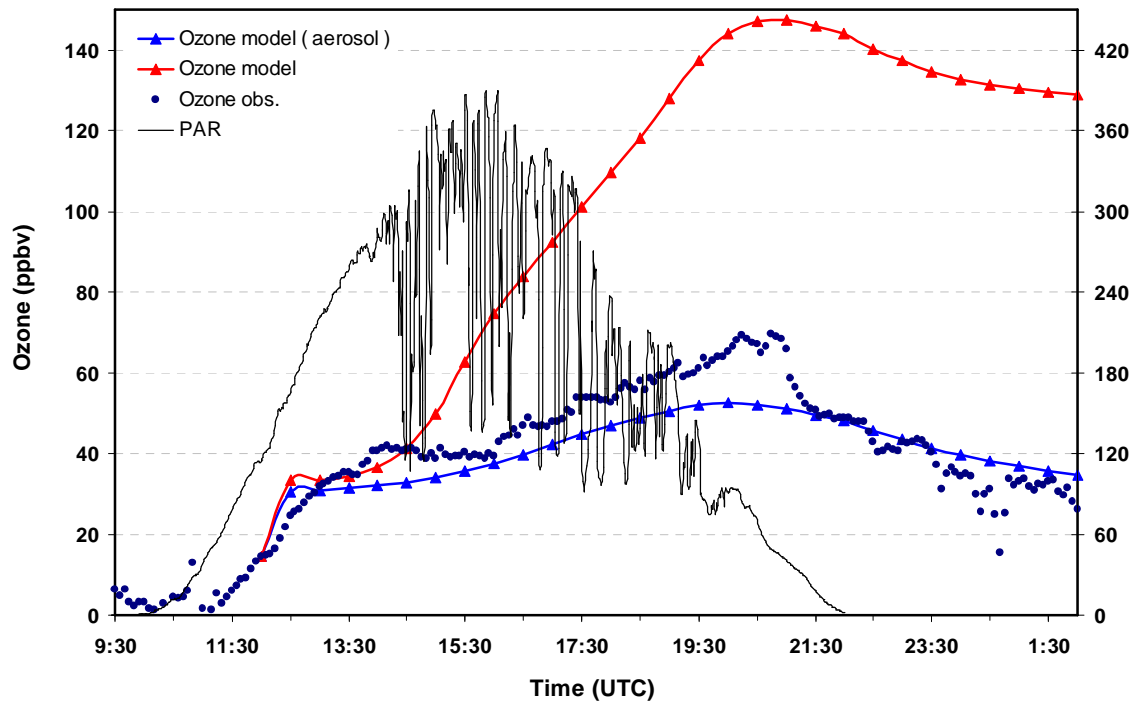

$5,9325-9353,2005$

Impact of smoke aerosol on the photolysis rates

L. M. M. Albuquerque et al.

Fig. 11. $\mathrm{O}_{3}$ observed at surface on 19 September 2002 at Fazenda N. Senhora site and the comparison with modeled $\mathrm{O}_{3}$ by the OZIPR model including (blue line) and neglecting (red line) the aerosol load concentration. The measured PAR surface irradiances $\left(\mathrm{Wm}^{-2}\right)$ are also shown to track the diurnal solar cycle.

Title Page

Abstract Introduction

Conclusions

References

Tables

Figures

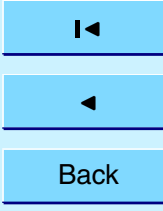

$>$ I

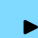

Close

Print Version

Interactive Discussion 